MILICA TAPAVIČKI-ILIĆ, ${ }^{1}$ Institute of Archaeology, Belgrade, Serbia

e-mail: mtapavic@sbb.rs

JELENA ANĐELKOVIĆ GRAŠAR, Institute of Archaeology, Belgrade, Serbia
UDC: 069.15:902/904(4)

Original research article

Received: September $5^{\text {th }} 2013$

Accepted: October $15^{\text {th }} 2013$

\title{
· OPENARCH, EUROPEAN PROJECT OF POPULARIZING ARCHAEOLOGY ${ }^{2}$
}

\begin{abstract}
OpenArch is a five year cultural project with eleven partners from eight European countries, based on EXARC's key strengths - its supportive community and international perspective. OpenArch aims to build a permanent partnership of archaeological open-air museums, raising standards among participants and improving the visitor experience across Europe. The web-site with all the relevant data: www.openarch.eu.
\end{abstract}

Keywords: OpenArch, EU cultural project, archaeological open-air museum, experimental archaeology, visitor.

The leading partner of the project is Calafell (CAT), while the other partners are Foteviken (SE), Kierikki (FI), Archeon (NL), Hunebedcentrum (NL), AÖZA (DE), Terramara di Montale (IT), National Museum Wales (UK), University of Exeter (UK), Viminacium (RS) and EXARC (NL). La Ciutadella Ibérica de Calafell (CAT) is a centre of experimental archaeology, an archaeological open-air museum where visitors can see what life was like in the Iron Age, 2.500 years ago. It is the first archaeological site in the Iberian Peninsula to have been reconstructed which used experimental archaeological techniques. More at www.ciutadellaiberica.com.

The Archaeological Open-Air Museum of Foteviken is situated $25 \mathrm{~km}$ south of Malmö (SE). It is situated within the city wall, open towards the sea, and represents the world's only attempt to recreate an entire Viking Age town. It shows a number of streets with 23 houses and homesteads, reflecting life in a late Viking Age and early Middle Age town in 1134 AD. More at www.foteviken.se.

The archaeological exhibition at the Kierikki Stone Age Centre (FI) displays objects from the Stone Age. In addition, activity programs in the reconstructed Stone Age Village offer a unique

1 During the symposium “Archaeological Heritage - its Role in Education, Presentation and Popularisation of Science”, held in Viminacium from 5-8. October 2012, the lecture entitled "OpenArch, European Project of Popularizing Archaeology” was presented by Milica Tapavički-Ilić and Jelena Anđelković Grašar. The content of this paper is vested in the beneficiaries, who possess the ownership on all of the reports and documents relating to it.

2 This project has been funded with support from the European Commission. This publication [communication] reflects the views only of the author, and the Commission cannot be held responsible for any use which may be made of the information contained there in. 
opportunity to experience life as it was lived thousands of years ago. Other attractions include a restaurant, hotel and museum shop. More data available at www.kierikki.fi. Founded in 1994, Archeon (NL) covers 10,000 years of human development in the Netherlands. From hunter-gatherers in the Stone Age and farmers in the Bronze and Iron Ages, through the Roman period and right up to everyday life in 1340 AD. "Archaeo-interpreters" show what life was like in "their time" in the 43 reconstructed buildings. Read more at www.archeon.nl.

Lying on the Hondsrug in Borger, in the north of The Netherlands, the Hunebedcentrum (NL) takes its visitors back to prehistoric times and shows the lives of the first farmers in Drenthe. They constructed impressive monumental tombs and the remains of 54 of them can still be seen, the largest of which stand right next to the centre. Find out more at www.hunebedcentrum.nl. The "Stone Age Park Dithmarschen" in Albersdorf (Schleswig-Holstein, DE) is being reconstructed as a Neolithic cultural landscape from ca. 3.000 BC. Lying close to megalithic tombs and grave mounds dating from the first farmers in Northern Germany, the site offers educational activities like flint knapping, archery and leatherwork. More at www.steinzeitpark-dithmarschen.de.

The terramara of Montale, near Modena (IT) is a typical Bronze Age settlement with pile dwellings surrounded with a ditch of water and imposing earthwork fortifications. Next to the site is an Open-Air Museum with life-size reconstructions of two houses furnished with replicas of the original finds dating back 3.500 years. Read more at www.parcomontale.it.

Amgueddfa Cymru, St. Fagans National History Museum is located to the northwest of Cardiff. The museum was created in 1946. in the grounds of St. Fagans Castle. It features dozens of reconstructed buildings, brought from across Wales, and three Iron Age roundhouses based on excavated examples. St. Fagans is one of Europe's leading open-air museums and has been voted one of the UK's favourite tourist attractions. Find out more under www.museumwales. ac.uk/en/stfagans.

Archaeology at the University of Exeter is a vibrant academic community offering excellent teaching and research. They are ranked 2nd in the United Kingdom for their world-leading and internationally recognised research and many staff publish on experimental archaeology. They offer high levels of student satisfaction and encourage students to use experimental methods. Read more at www.exeter.ac.uk/archaeology.

Viminacium is an ancient Roman site on the right bank of the Danube in eastern Serbia. In an area of about 450 ha, there are the remains of a military camp, a city and cemeteries. Remains of a Roman bath, a mausoleum, an amphitheatre and one of the gates of the military camp can be seen, as well as a replica of a Roman villa. More at www.viminacium.org.rs. EXARC is the ICOM Affiliated Organisation representing archaeological open-air museums and experimental archaeology. EXARC raises the standard of scientific research and public presentation among its membership through collaborative projects, conferences and publications. More data available at www.exarc.net.

\section{PROJECT'S FOCUSES}

The main idea of archaeological open-air museums is to present both the tangible and intangible past to the public. The tangible parts of Archaeological Open-Air Museums are the archaeological remains and the reconstructions of these (houses, tools, complete environments). The intangible and most interesting part of an archaeological open-air museum is the story of the people that once lived there. One of the project's focuses is to revive the past as much as possible, in the best possible way. This is why the work in OpenArch is divided into Work Packages. All Work Packages are the responsibility of the entire partnership, but one or two partners coordinate them.

\section{MEETINGS AND WORKSHOPS}

OpenArch meetings are theoretically focused events, with presentations/lectures and discussion groups. These are open and of interest to a broader audience. Workshops are practically focused 'working together' gatherings for staff of the archaeological open-air museums with the aim of exchanging insight into specific methods and improving each oth- 
er's skills/abilities. At every workshop within the OpenArch project, different Work Packages are addressed, as modules. The workshops and meetings are open to staff and other interested persons from outside the organiser museums. Several meetings have taken place so far. After the kick-off meeting in January 2011. in Calafell and the meeting in October 2011. in Borger, participants met again in April 2012. in Modena (IT). The meeting dealt with the implementation of the OpenArch project activities, with a specific focus on the Dialogue with Skills, a topic coordinated by the Italian partner in cooperation with the German partner Archäologisch-Ökologisches Zentrum Albersdorf. The core of the program was the workshop "Smiths in Bronze Age Europe”, planned with a pedagogical and hands on approach. Its aim was to provide a reference guide for skilled experts and craftsmen as well as managers dealing with Bronze Casting presentations in Archaeological Open-Air Museums.

The meeting in September 2012. in Foteviken (SE) followed, during which the over-arching theme was the challenges of interpreting and engaging public interest in open-air museums and archaeological/ historic sites. For two days, the linked themes "Management \& communication strategies at open-air/archaeological museums", "Working with volunteers" and "How can performance of various kinds contribute to and extend the work of such museums and sites?” were discussed.

In April 2013, all of the OpenArch partners met in Archeon (NL). The conference revolved around "The Dialogue with the Visitor". Archaeological open-air museums (AOAM) face unique challenges concerning their interaction with visitors. Through themes concerning the Story of the Site and the Visitor's Experience, the participants explored these challenges and how to meet them. During the conference, speakers from various disciplines and backgrounds engaged visitors and each other on diverse subjects. The goal was to gain a better understanding of both the stories we tell - the intangible heritage preserved by AOAM - and how the visitor experiences these. The participants also looked at best practices in (games) design, theatre, amusement parks and others. Additionally, there were work- shops and demonstrations of historical food preparation, as well as lectures on the subject. In September 2013, the meeting was held in AÖZA (DE). Since the Albersdorf museum is participating in the "Dialogue with skills", the main topic during this conference was "Stone in Prehistory”. Furthermore, an international scientific conference was organised about archaeological research and experiments. There were also practical workshops at the open-air museum, with demonstrations and different activities regarding working with stone. At the public forum, there was time and space for an intensive exchange of experiences and ideas. During the last day of the conference, a site visit took place on the traces of landscapes and settlement history on the North Sea coast.

\section{STAFF EXCHANGES}

Staff Exchanges within the OpenArch project are considered to be a tool for the interchange of best practices between staff of different museums. The target-groups of staff exchanges are the day to day workers of the museum, the ones that are closer to the general public and schools. Mainly, by means of this activity, the participants of the project reach one of the EU objectives: to enhance the cross-border mobility of artists and workers in the cultural sector. The staff exchanges have predefined themes. They are mainly prepared by the frontline staff of the museum, i.e. by the cultural actors and artists. The University of Exeter, Department of Archaeology (UK) is organising various workshops for OpenArch partners' staff, where they can learn more about experimental archaeology, not just the academic background, but much more on how this can be applied in archaeological open-air museums. Two workshops are planned every year, with about three museums participating each time. Subjects range from house construction to publishing and didactics.

\section{EXPERIMENTAL ACTIONS}

Archaeological remains and objects are tangible remains of past civilizations. They need to be interpreted to give meaning today, 
and interpretation is dependent on experiments. Experiments and experimental actions are needed to understand how objects were made, how constructions might have appeared and, not least, how people in the past behaved. Some of the OpenArch experimental actions included pottery making, constructing a Stone Age hut, skinning a reindeer, making drums of leather, making a trunk boat, performing a "Roman" cremation and planting "Roman” grapevine.

\section{BRINGING THE MESSAGE TO THE IN- TERESTED}

OpenArch has several means of bringing our message to those people who may be interested. The EXARC Journal is published both in hard copy and online. Besides that, several websites reach thousands of people. The websites are being updated several times per week. The Community Manager is also active on several social media, including LinkedIn, Facebook and Twitter. Here people are notified about new activities and products, updates from our partners and much more. Search for 'experimental archaeology' or 'archaeological open-air museums’.

\section{REZIME}

\section{OPENARCH, EVROPSKI PROJE- KAT POPULARIZACIJE ARHEO- LOGIJE}

Ključne reči: OpenArch, projekat kulture Evropske Unije, arheološki muzej na otvorenom, eksperimentalna arheologija, posetilac.

OpenArch je petogodišnji projekat kulture Evropske Unije, koji obuhvata jedanaest partnera iz osam evropskih zemalja. Cilj projekta je da se oformi dugotrajno partnerstvo među učesnicima - arheološkim muzejima na otvorenom. Projekat obuhvata izvođenje arheoloških eksperimenata, razmenu muzejskog osoblja i intenzivan dijalog sa posetiocima, u cilju dobijanja podataka o tome kako oni doživljavaju ovakve muzeje. Istovremeno se, u okviru projekta, radi na dijalogu sa naučnicima-arheolozima, radi formiranja određenih standarda za izvođenje arheoloških eksperimenata, ali i sa zanat- lijama, čija je pomoć često neophodna kada su u pitanju ovakvi eksperimenti. Najzad, projektom je predviđena izrada većeg broja publikacija i multimedijalnih prezentacija vezanih za teme projekta. 